論文

UDC $669.162 .263 .43: 669.162 .28$

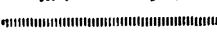

\title{
層状装入粒子充塡層わよび移動層のガス流れ*
}

\author{
荒木 和 男**.森山昭**
}

\section{Gas Flow through Packed and Moving Beds with Layered Burdens}

\section{Kazuo ARAKI and Akira MoriYama}

\begin{abstract}
Synopsis :
Gas flow patterns and pressure profiles through packed and moving beds with layered burdens have theoretically and experimentally been studied.

In the middle region of the beds, periodic behaviours of gas flow correspond with the alternative packings of the beds. In the top and the bottom region, gas flow tends to concentrate to a lower resistant part of the beds. The velocity profiles of gas flow at the inlet part of the beds cannot be described with such a simple expression as a linear equation. Usually, the total pressure drop through the beds is smaller than the estimation based on "parallel-flow model."

Flow patterns of gas in the top region of the beds are not very affected by the packing structure of the botttom region of the beds and similarly flow patterns in the bottom region are not affected by the packing of the top region.

The third layer imposed in the bottom part of the beds, an inclination of top surface and angles of repose of the packed burdens also have a considerable effect on both pressure profiles and flow patterns through the beds.
\end{abstract}

1. 緒言

不均一充媜構造粒子充塤層で，軸方向流通抵抗の不均 一性が半径方向で変化する場合, 半径方向ガス流れ,す なわち，クロス流が存在する1) -3)。このため，さまざま な不均一充埚構造には，それぞれ特有の不均一ガス流れ が伴うことになり, 不均一充填構造をもつ充㘿層型反応 器内のガス濃度分布, 温度分布, さらには器内の反応過 程が，ガス流れの不均一性によつて大きな影響をうける ものと考えられる. 高炉内のガス流れ問題についても, 最近, ようやくこうした不均一充媜構造に伴うクロス流 の問題に注意が払われるようになつだ(5)15).

従来, この種の問題の理論的研究では, 2 次元場に拡 張した Ergun 式と連続の式とを基礎式として採用して いる.これは固有流通抵抗の実測值を使用するかぎり， Ergun 式が信頼度の高い半理論式である点から, 妥当 な研究手法であるといえよう.しかし，この基礎式系の 解析解導出は困難であるため, 数値解析に基づく場合が 多(5) 7)(5). その際, ガス流入部の流速分布を簡単な数 式で仮定しているので，結果の現実性を保証するには，
少なくとも，この仮定の妥当性が十分立証される必要が ある.一般にガス流入部の流速分布は充壃構造に依存し て複雑な分布をとるはずであり，たとえば，不均一充塤 構造充堛層汇関して V.STANEK $5^{6 / 7)}$ の等流量流入条件 を採用した解析の問題点は，筆者ら 2 3)をはじめ，その後 も, 他の研究者(5)8 のしばしば指摘するところである. 層 状装入された高炉炉胸部のガス流れに関する桑原ら (5)15) の数值解析では，ガス流入部流速分布を 1 次式（流れ関 数について 2 次式）で仮定している. また, 彼ら5(6)15)の 解析には基礎式についても若干検討の余地があるように 思われる.なお，Ergun 式に基づくかぎり，層流域の みならず，乱流域においても，流線と等压線は直交すべ きことが示される゙)*.

問題を高炉内ガス流れに限定する場合，充坫構造以外 に，炬形状，送風羽口からのガス吹き込みも，不均一な ガス流れの一因と考光られる。これらについては，J.

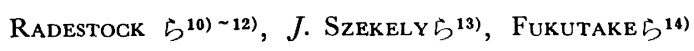
および习习习田野ら ${ }^{8)}$ の最近の研究が知られている.しかし， これらに起因する不均一ガス流れ問題の定量的把握はき

*別報9)で群細に述へる.

* 昭和 51 年 10 月本会講演大会にて発表 昭和 51 年 9 月 22 日受付 (Received Sept. 22, 1976)

** 名古屋工業大学材料開発研究施設 工博 (Material Research Laboratory, Nagoya Institute of Technology, Gokisho-machi Shōwa-ku Nagoya 466) 
わ放て不十分であり, 前提条件として, 地道な基礎現象 の解明が和要な段階にあると考える.

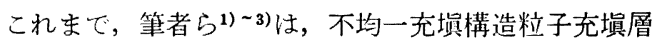
内のガス流れを実験および理論の両面から検討する中 で，2次元的および軸対称系の層流域におけるガス流れ に関する分布定数系モデルを提出し，その妥当性を明ら かにした。

本報では，前報3)で示した手法に基づき，高炬などの 実際プロセスを意識して，層状装入粒子充嚗層および移 動層の層流域におけるガス流れに及ぼす諸因子の影響に ついて基礎的考察を試みる。

\section{2. 理論}

前報3)で詳細に述べたように，層状装入粒子充堌層の 半径方向を $n$ 分割し, 層 $1,2 \cdots \cdots, n$ と名づけ, 各層 内の軸方向不均一境界を階段近似する.この結果, 軸方 向は $m$ 区間に分割されるものとする. 前報3)では，ガス が充塡層上部から流下する場合について解析したが，本 報は上昇流の場合であり，ガス流れに関する基礎式は， 前報3の基礎式で $\nu_{i}^{j}$ をー $\nu_{i}^{j}$ で置きかえた形となる. 与 えられた連立常微分方程式を, 前報 3 と同様にして，「層 底および層頂で圧力一定」の条件下で解き, 行列形式に 基づくガス流速と圧力の分布に関する理論解が導出でき る.

なお，等圧線上流線は，理諭解に基づいて求められた 各格子点の圧力および流速から, 内挿法あるいは外插法 によつて求める. その際, 半径方向分割数を少なくする と，とくに流線が密な領域で，内挿（外捕）法に基づく 誤差を生ずる. 前報3)の Fig. 5 には，このような誤差 が含まれている.この場合, 半径方向分割数をふやし, 区間幅 $\partial_{i}$ を小さくすれば精度が向上する. 本報の計算 では, 半径方向分割数を 20 にふや, さらに, 行列演 算を 2 倍精度から 4 倍精度に強化した*。

\section{3. 層状装入粒子充填層のカス流れ}

\section{1 理論値と実測值の比較}

実験装置および方法は前報3)と同一であるが，今回は 層内ガス圧力のほかに，ガス流入部での流速分布を熱線 風速計を用いて測定した.

Fig. 1 の曲線 $\mathrm{a} \sim \mathrm{m}$ は層内ガス圧力分布, また, 曲線 $\mathrm{n}$ は流入部のガス流速分布の代表例で, 層 $\mathrm{A}$ と層 $\mathrm{B}$ の安 息角 $\theta_{\mathrm{A}}$ および $\theta_{\mathrm{B}}$ がともに $30^{\circ}$, 固有流通抵抗比 $\beta=$

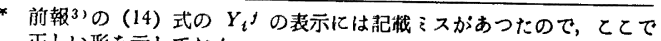
正しい形を示しておく $Y_{i}^{j}=2 c^{2}\left(k_{i}^{j} / \delta_{i}+k^{j} j_{i+1} / \delta_{i+1}\right) /\left(h_{i} j\left(\delta_{i}+\delta_{i+1}\right)\right\}$ 前報ぶの計算には, 正しい式を用いている.
}

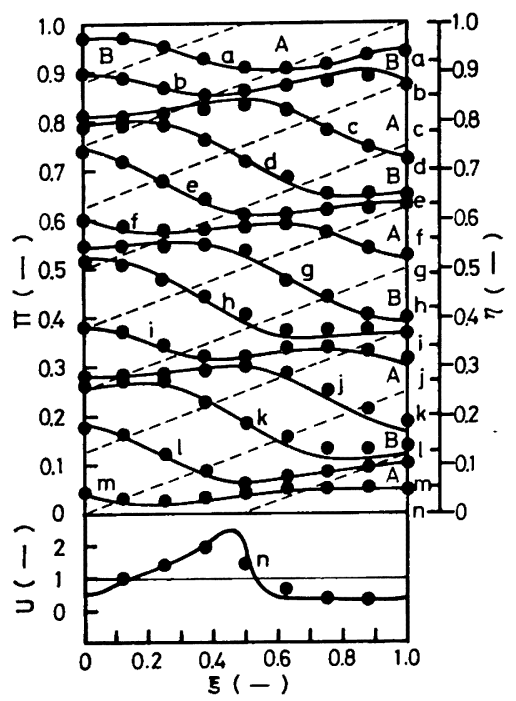

Fig. 1. Pressure distributions through the packed bed with layered burdens and inlet gas velocity profiles ( marks), compared with theoretical curves. The small English letter indicates the axial position of measuring point. $\beta=9.8, \quad d_{p \mathrm{~A}}=0.5 \mathrm{~mm}, \quad d_{p \mathrm{~B}}=1.51$ $\mathrm{mm}, \theta_{\mathrm{A}}=\theta_{\mathrm{B}}=30^{\circ}, R e \approx 1$.

9.8 の場合である.なお，Fig. 1 中の記号 $\mathrm{a} \sim \mathrm{n}$ は，同 図右端の座標上に示す測定点にそれぞれ対応している.

実線で示す理論值は，印で示した実測値とよく一致 するので, 本報の解析手法は, 層状装入粒子充買層のガス 流れを実際に十分予測できる方法であることがわかる.

ガス流入部のガス流れの問題については，前述したよ うに，ほとえど正確な知見がないのであるが，Fig. 1 の 理論および実測結果によつて，層底部の流通抵抗が小さ い部分にガス流れが集中する傾向を示し，その分布を簡 単な数式近似することが一般に困難であることがわか る.

\section{2 層内ガス流れおよび全圧損失}

Fig. 1 の層状装入充堛層に関する理論流線と等圧線を Fig. 2 に示した. ただ，この場合， $\beta=10$ とした.

罒より明らかなように，層の中間領域では充堤構造の 空間的周期性に起因して，ガス流もほぼ周期的な変動を 示し5)，層底および層頂部近傍において，相対的に小さ い流通抵抗部分にガス流れが集中して流入もしくは流出 することがわかる。

充垻層を通しての全圧損失の理論値は $\pi_{t}=0.440$ (す なわち， $\left.P_{t}=0.440 \rho_{\mathrm{A}} l Q / L W\right)$ となり，クロス流を考 虑しない並列モデルから計算した全圧損失 $\pi_{t}=0.550$ に 対して, $20 \%$ も減少する.なお， $\beta=9.8$ の場合，全圧 


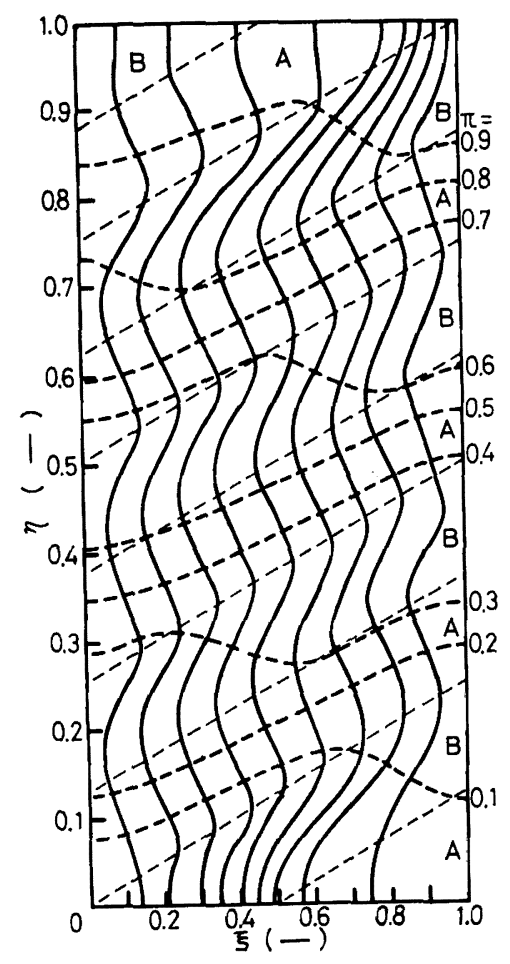

Fig. 2. An example of isobars and streamlines in the packed bed with layered burdens. $\beta=10, \theta_{\mathrm{A}}=\theta_{\mathrm{B}}=30^{\circ}$.

損失の実測值は $\pi_{t}=0.457$ であり, 並列モデルに基ゔ く計算值 $\pi_{t}=0.551$ と比較して, $17 \%$ 隇少している. 一般に, 層状装入粒子充塡層の全圧損失は, 並列モデル の計算值に比較して，つねに小さくなる。

\section{4. 層底部に挿入した第 3 の層の影響}

層底部に存在する第 3 の層 $\mathrm{C}$ (例えば，高炉炉志)が, 層内ガス流れにおよぼす影響について述べる.ここで， 第 3 の層として, Fig. 3 左下に示すような 3 角形状の層 を想定した.

Fig. 3 の各点線は, $\rho_{\mathrm{C}}=0.1 \rho_{\mathrm{B}}, \beta=10$ の場合につき 理諭的に求めた流線で, 実線で示した流線は第 3 の層 $\mathrm{C}$ を含まない Fig. 2 の場合の流線である.

一般に, 層 Cの固有流通抵抗 $\rho_{\mathrm{C}}$ が層 $\mathrm{A}$ のそれ $\rho_{\mathrm{A}} よ$ り大きい場合には，ガス流は層 $\mathrm{C}$ を迂回して流れる傾向 を示し， $\rho_{\mathrm{B}}$ が相対的に $\rho_{\mathrm{A}}$ より小さくなるにつれて層 Cを流れるガス流量が急激に増大し, とくに, $\rho_{\mathrm{C}} \leqslant \rho_{\mathrm{B}}$ では, 層底部付近の A 層内へはほとんどガスが流れない。 またガス流入部の流速分布は，Fig. 4 の実線で示すよう に第 3 の層 $\mathrm{C}$ の性質によつて,大きな差異を示す.なお，

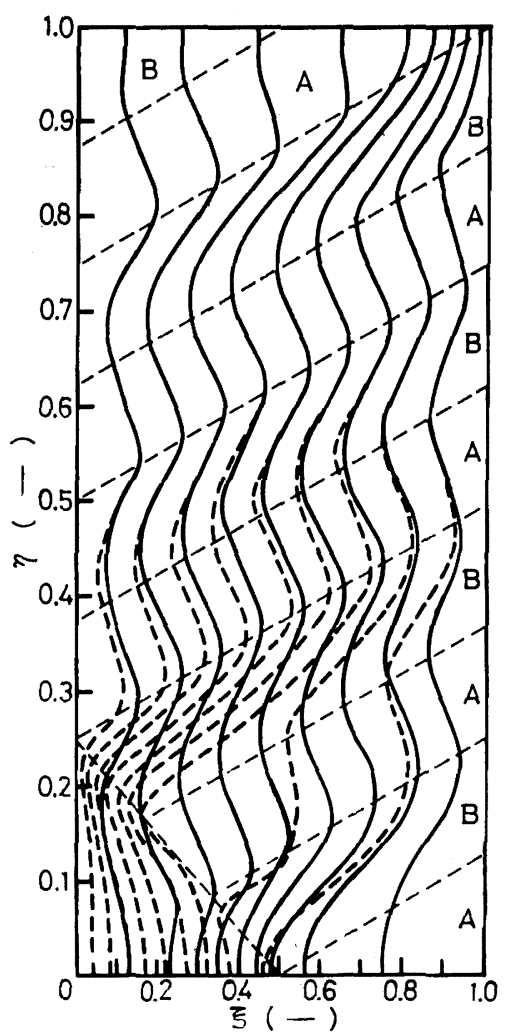

Fig. 3. Streamlines in the bed with an imposed third layer $\mathrm{C}$ at the bottom (dotted lines), and those without the third layer $\mathrm{C}$ (solid lines). $\beta=10, \theta_{\mathrm{A}}=\theta_{\mathrm{B}}=30^{\circ}, \rho_{\mathrm{C}}=$ $0.1 \rho_{\mathrm{B}}$.

同図の点線は，第 3 の層 $\mathrm{C}$ を含まない場合の流速分布 (Fig. 9， $\tau=0$ の実線) である.

以上のように, 層底部のガス流れ挙動は，層底部に存 在する第 3 の層 $\mathrm{C}$ の性質に大きく左右され，流線憎 $\mathrm{C}$ が存在しない場合のそれ (Fig. 2 および Fig. 3 実線) から大きく偏倚し，その影響は層の中間領域にまでおよ ぶ. ただ，層頂部付近のガス流れは，第 3 の層の存在に よつてほとんど影響されることがなく，流線は層 $\mathrm{C} か ゙$ 存 在しない場合の層頂部付近の流線にほぼ一致する（Fig. $3)^{15)}$. このように，一般に，層底部におけるガス流れ挙 動は，層底部の充填状況の影響を強くうけるが，一方，

層頂部付近のガス流れ挙動は層底部の充塡状況，したが つて，層底部に打けるガス流れ挙動にあまり左右されな い. したがつて, 数值解析にあたつて, 層底部の速度分 布を仮定し層頂部で判定を行ない仮定值の修正をする計 算方式を採用する場合，層全体にわたつて精度良い計算 結果を得るためには, 適切な流速分布形および判定条件 


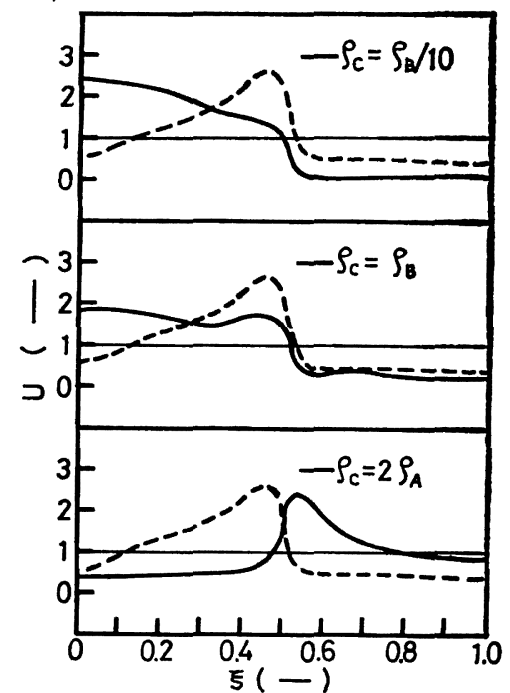

Fig. 4. Velocity profiles of gas at the inlet part of the bed with an imposed third layer $\mathrm{C}$ (solid lined), and those without the third layer $\mathrm{C}$ (dotted lines). $\beta=10, \theta_{\mathrm{A}}=\theta_{\mathrm{B}}=$ $30^{\circ}$.

の設定に十分な注意が必要となる.

層底部に第 3 の層 $\mathrm{C}$ が存在する場合の充逥層を通して の全圧損失は,

(a) $\rho_{\mathrm{C}}=2 \rho_{\mathrm{A}}$ の場合, $\pi_{t}=0.517(17.5 \%$ 増)

(b) $\rho_{\mathrm{C}}=\rho_{\mathrm{B}}$ の場合, $\pi_{t}=0.385(12.5 \%$ 減 $)$

(c) $\rho_{\mathrm{C}}=0.1 \rho_{\mathrm{B}}$ の場合, $\pi_{t}=0.348(20.9 \%$ 减 $)$

となる. 末尾の（）の数值は, 層 $\mathrm{G} か ゙$ 存在しない場合 の全圧損失 $\pi_{t}=0.440$ と比較した増減率を示している.

\section{5. 傾斜層頂面をもつ居状装入充填曾の ガス流れ}

\section{$5 \cdot 1$ 傾斜層頂面の影響}

高炉などにみられる傾斜層頂面をもつ充塡層について 検討した.この種の充垻層の代表的な等正線と流線を Fig. 5 に示す. $\left(\theta_{\mathrm{A}}=\theta_{\mathrm{B}}=30^{\circ}, \beta=10\right)$.

一般に，層頂部近傍では, 傾斜層頂面の影響をうけて， 流線が中心側（ $\xi=0$ 付近）へ偏倚し，層頂部では層頂 面に直交する5).Fig. 5 に示した例の場合，層頂部での 中心部ガス流速は, 周辺部（ $\xi=1$ 付近）のそれの 6.6 倍にもなる.しかしながら，このような中心偏倚傾向は 層頂部近傍に限られており, 層の中間領域では傾斜層頂 面の影響をうけていない.ちなみに, Fig. 5 に示した層 底部および中間領域の流線は，Fig. 2 に示した流線にほ ぼ一致する. すなわち, 層底部のガス流れ挙動は, 層頂

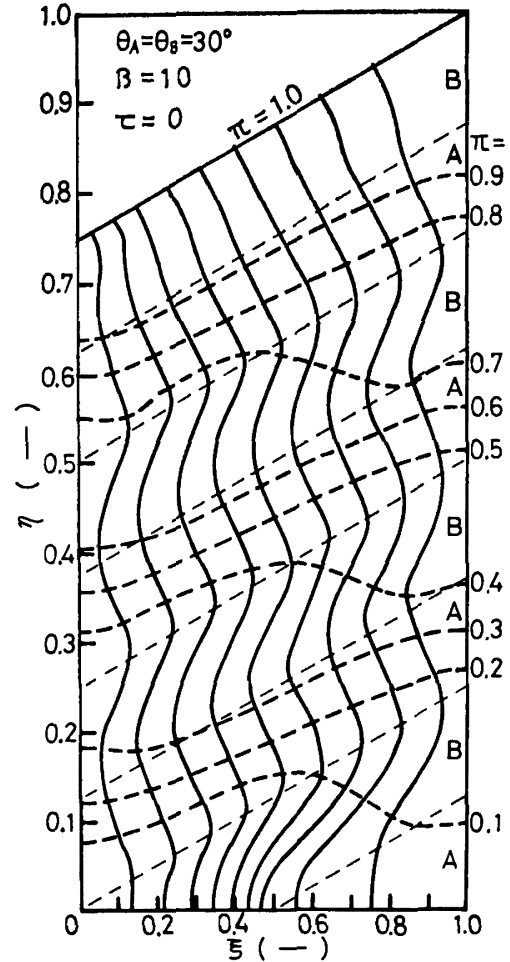

Fig. 5. A typical example of isobars and streamlines in the bed with inclined surface of the burden.

部の充垻状況の影響をうけることはない.したがつて， 4 章で得られた結果をも考虑すると，一般に，層底部の ガス流れ挙動は層頂部充塡状況により，逆に，層頂部の 流れ挙動は層底部充塡状況（したがつて，ガス流れ挙動） によつて左右されないと結論できる.

\section{$5 \cdot 2$ 安息角の影䋨}

前節では層 $A$ と層 $B$ の安息角が等しい場合について， 層頂面の傾斜とガス流れ挙動を論じた。一方，高炉では コークス層と鉱石層の見かけの安息角が異なると思われ る. 安息角が異なると，各半径位置での軸方向流通抵抗 が，半径位置の関数として単調に増減するので，安息角 が等しい場合と比較して，中心流あるいは周辺流の一方 的な強化につながるものと考えられる。

いま，代表例として， $\theta_{\mathrm{A}}=20^{\circ} ， \theta_{\mathrm{B}}=30^{\circ}$ および $\beta=$ 10の場合について，傾斜層頂面をもつ層状装入充馘層内 の流線を計算した結果が，Fig. 6 の実線である.図には 比較のため, $\theta_{\mathrm{A}}=\theta_{\mathrm{B}}=30^{\circ}$ の場合の流線を点線でえがい てある. Fig. 6 に示した例では, $\theta_{\mathrm{A}}=\theta_{\mathrm{B}}=30^{\circ}$ の場合に 比較して, 周辺側流通抵抗が相対的に減少するので, 周 辺側にガス流が偏倚する.なお， $\theta_{\mathrm{A}}=30^{\circ}, \theta_{\mathrm{B}}=20^{\circ}$ の 


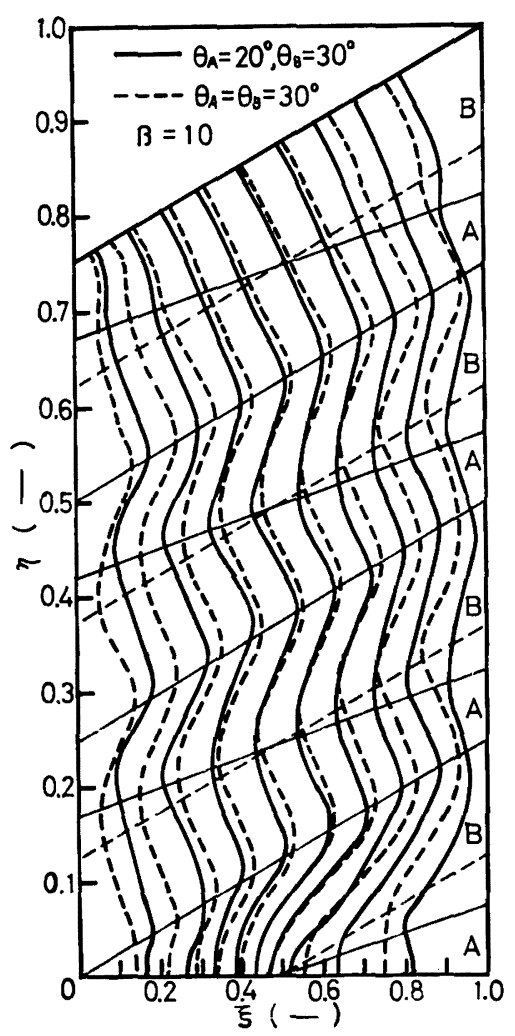

Fig. 6. Gas flow patterns through the bed where $\theta_{\mathrm{A}}=20^{\circ}$ and $\theta_{\mathrm{B}}=30^{\circ}$ (solid lines) and $\theta_{\mathrm{A}}$ $=\theta_{\mathrm{B}}=30^{\circ}$ (dotted lines).

場合には，ガス流が中心側入偏倚する.

ガス流入部 $(\eta=0)$, 層の中間部 $(\eta=0.5)$ および層 頂面でのガス流速の増隇割合は, $\theta_{\mathrm{A}}=\theta_{\mathrm{B}}=30^{\circ}$ の場合の 対応する点のガス流速を基準として, Fig. 7 のように表 わされる. この場合, 基準流速は, Fig. 9 の $\tau=0\left(\theta_{\mathrm{A}}\right.$ $\left.=20^{\circ}, \theta_{\mathrm{B}}=30^{\circ}\right)$, および, $\tau=0.6\left(\theta_{\mathrm{A}}=30^{\circ}, \theta_{\mathrm{B}}=20^{\circ}\right)$ に対応する. Fig. 7 は，上述した中心側または凬辺側人 のガス流の偏倚をきわめて明瞭に示している.

\section{6. 層状装入移動層内ガス流れ}

高炉のように，粒子降下速度が，ガス流速に比較して 十分打そい層状装入粒子移動層においては，ガス流れは 各僢間に定常状態を保ちつつ時間的に推移するものと考 えられる. したがつて, 各瞬間の充塤構造に対する定常 ガス流れ挙動を求めることによつて，この種の移動噟内 ガス流れを予測できる.しかも，層状装入粒子移動層で は, ある一定周期ごとに同一充塡状態がくり返されるの で，一周期間のガス流れ挙動を知れば十分である.

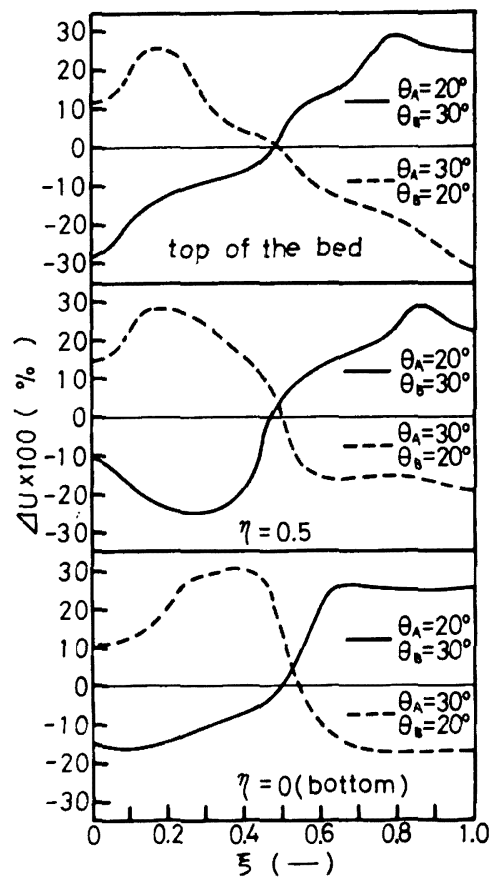

Fig. 7. Increased and/or decreased ratios of the flow velocity of gas referred to those where $\theta_{\mathrm{A}}=\theta_{\mathrm{B}}=30^{\circ}$.

本報では，Fig. 5 に示した充鲑状況を初期状態として 層状装入粒子移動層のガス流れにつき解析した．Fig. 8 は $\tau=0.6$ における流線と等王線の理論計算值である. 3.2 節でも述べたように，一般にガス流れは，層底部で 流通抵抗が相対的に小さい部分に集中し，層の中間領域 で充埧椿造の空間的周期性に対応して蛇行する.しかし 傾斜層頂面をもつ場合は，一般に，層頂部のガス流れは 充題状況にかかわらず中心側に偏流する傾向を示す.こ のことは，各瞬間のガス流入部および層頂におけるガス 流速分布から，よりいつそう明瞭に理解される(Fig. 9). また，層頂部の中心部ガス流速は，周辺部のそれの数倍 (2〜7 倍程度) にもなる（Fig. 9 点線).

移動層の場合，全压損失は，Fig. 10 に示すように, 㭙間的に周期变動する. この場合 $\left(\theta_{\mathrm{A}}=\theta_{\mathrm{B}}=30^{\circ}, \beta=\right.$ $10)$, 周期変動の振幅は, 全圧損失の時間平均值の約 7.5 $\%$ \%大さで，時間平均值は $\bar{\pi}_{t}=0.402$, すなわち, $\bar{P}_{t}=0.402 \rho_{\mathrm{A}} l Q / L W$ である.

層状装入移動層では, 充嚗構造が時間に関して周期变 動する.この場合も含めて, 一般に, 不均一充堹構造移 動層の充嚗椿造が時間的に変化するような場合の層内ガ ス流れの考察にあたつては, 入ロガス流入流速分布を境 


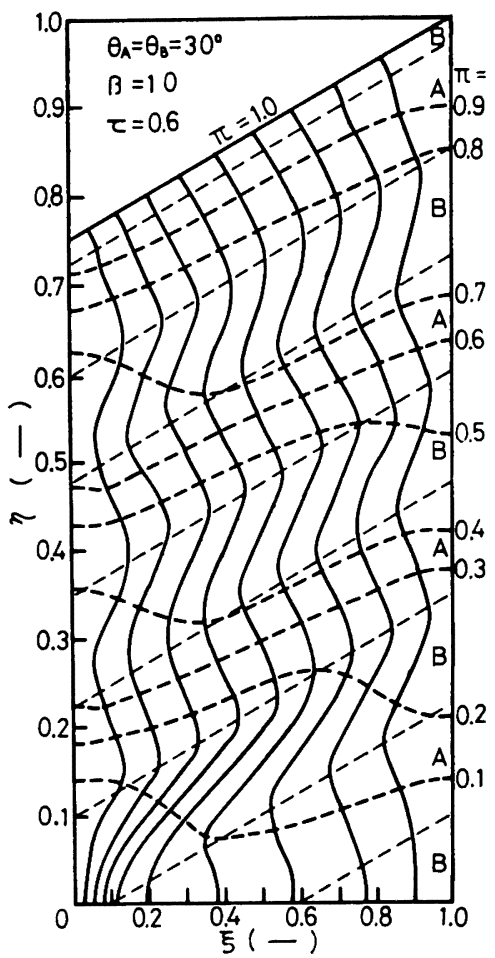

Fig. 8. Example of calculated isobars and streamlines in the moving bed with layered burdens. $\beta=10, \theta_{\mathrm{A}}=\theta_{\mathrm{B}}=30^{\circ}, \tau=0.6$.

界条件の 1 つして使用する解析手法は適当ではないよ うである.この点は，すでに指摘した，ガス流入流速分 布の数式表現の妥当性の問題とともに，この種の取扱い の短所の一つであると考えられる.

\section{7. 結言}

不均一充埧構造粒子充壃層について前報3)で提出した 解析手法に基うきき，高炉などの実際プロセスを念頭にお いて，層状装入粒子充償層および移動層の層流域におけ るガス流れに関する基礎的考察を展開した。

層状装入粒子充填層の中間領域では，充塓状況の空間 的周期性に対応して，ガス流れが周期的に変動する. し かし，層底部および層頂部では, 相対的に小さい流通抵 抗部分に流入あるいは流出ガスが集中する傾向が認めら れる.また，流入部におけるガス流速分布は充嚗構造に 依存して複雑となるため, 一般に, 簡単な数式近似は困 難であることがわかつた。

層を通しての全圧損失は，一般に，クロス流を考慮し ない並列モデルに基うくくれれりも小さくなる.

層底部に第 3 の層（例えば，高炉炉芯）が存在する場

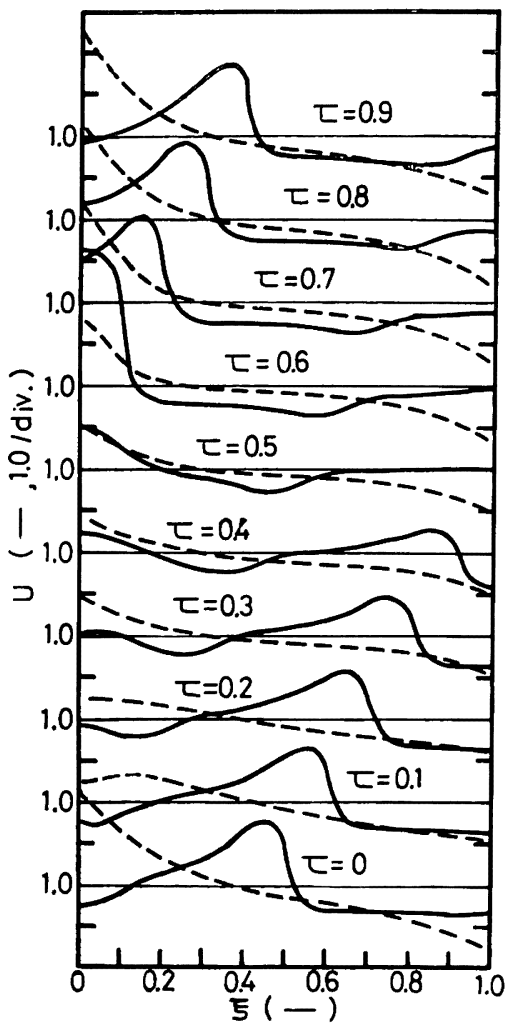

Fig. 9. Velocity profiles of gas at the bottom (solid lines) and the top (dotted lines) of the moving bed where $\beta=10$ and $\theta_{\mathrm{A}}$ $=\theta_{\mathrm{B}}=30^{\circ}$.

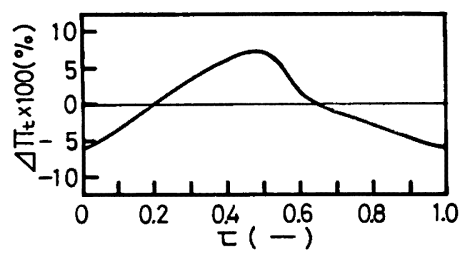

Fig. 10. Change of the total pressure drop through the moving bed with dimensionless time. $\beta=10, \theta_{\mathrm{A}}=\theta_{\mathrm{B}}=30^{\circ}, \bar{\pi}_{t}=0.402$.

合，層底付近のガス流れに大きな影響が現われ，それは 層の中間領域にまでおよぶ.しかし，層頂付近のガス流 れは，第 3 の層の影響をほとんどうけない。一般に，層 底および層頂付近のガス流れは，それぞれ，層頂および 層底部の充壃状況，したがつて，ガス流れにあまり影響 されない.このため，この種の問題の数值解析にあたつ ては，妥当な境界条件の設定に十分な留意が必要であ る. 傾斜頂面をもつ充填層では，層頂付近のガス流が中 心側に偏流する傾向を示す.この層頂面傾斜の影響は層 
頂面付近に限られるが，流出ガス流速の不均一性はきわ めて大きい。

層状装入された両層の安息角が異なる場合, 固有流通 抵抗が大きい層の安息角の相対的大小関係に応じて，中 心流あるいは周辺流が強化される.

ガス流速に比較して粒子降下速度が十分におそい層状 装入粒子移動層のガス流れは，一定の周期をもつて時間 的に変動する. 同時に, 移動層を通しての全圧損失も， 時間的平均値のまわりに周期的に变動する。

\section{記 号}

c：充填層の幾何学的形状因子 $l / L,(-)$

$d_{p \mathrm{~A}}, d_{p \mathrm{~B}}$ : 層 $\mathrm{A}$ および $\mathrm{B}$ 層の充填粒子㺯， $(\mathrm{mm})$

$h_{i}^{j}$ : 層 $i$ と層 $(i+1)$ 間のクロス流に対する単位層高あ たり無次元流通抵抗，(一)

$k_{i}^{j}:$ 軸方向無次元固有流通抵抗，(-)

$L$ : 充填層幅， $(\mathrm{cm})$

$l$ : 充填層高, $(\mathrm{cm})$

$m:$ 軸方向分割数（区間数）

$n:$ 半径 (横) 方向分割数

$P_{t}:$ 全压損失, $\left(\mathrm{cm}\left(\mathrm{H}_{2} \mathrm{O}\right)\right)$

$Q:$ 全ガス流量, $\left(\mathrm{cm}^{3} / \mathrm{sec}\right)$

$R e:$ レイルズ数，(一)

$T$ : 層状装入移動層における同一充媜状態くり返し周 期, ( sec)

$U:$ 空塔速度基準無次元ガス流速，(一)

$\Delta U:$ :ガス流速增減率，(-)

$W:$ 充埧層厚さ, $(\mathrm{cm})$

$x$ : 半径 (横) 方向距離, $(\mathrm{cm})$

$y$ : 層内高さ, $(\mathrm{cm})$

$\beta$ : 層 $\mathrm{B}$ の固有流通抵抗に対する層 $\mathrm{A}$ の固有流通抵抗 の比, (-)

$\xi$ : 無次元半径 (横) 方向距離 $x / L,(-)$

$\eta:$ 層内無次元高さ $y / l,(-)$ $\delta_{i}:$ 無次元分割層幅 $d_{i} / L,(-)$

$\rho_{\mathrm{A}}, \rho_{\mathrm{B}}, \rho_{\mathrm{C}}$ : 層 $\mathrm{A}$, 層 $\mathrm{B}$, 層 $\mathrm{C}$ の固有流通抵抗, $\left(\mathrm{cm}\left(\mathrm{H}_{2} \mathrm{O}\right) \cdot \mathrm{sec} / \mathrm{cm}^{2}\right)$

$\nu_{i}^{j}$ : 層 $i$, 区間 $j$ を流れる無次元ガス流量 $Q_{i}^{j} / Q$, $(-)$

$\pi$ : 全圧損失基準無次元ガス圧力， (-)

$\pi_{t}: \rho_{\mathrm{A}} l Q / L W$ 基準無次元全圧損失, (

$\bar{\pi}_{t}: \pi_{t}$ の時間平均値， $(-)$

$\Delta \pi_{t}: \pi_{t}$ の增隇率 $\left(\pi_{t}-\bar{\pi}_{t}\right) / \bar{\pi}_{t},(-)$

$\theta_{\mathrm{A}}, \theta_{\mathrm{B}}$ : 層 $\mathrm{A}$ および層 $\mathrm{B}$ の安息角，（度）

$\tau$ : 周期 $T$ 基準無次元時間, (-)

\section{交献}

1）森山昭，西尾賢一：鉄と鋼，60(1974)，p.1271

2 ) 荒木和男，森山昭，西尾賢一：鉄と鋼，60 (1974), p. 2085

3 ）荒木和男：鉄と鋼，62(1976)，p. 1485

$4 ）$ 下村泰人, 九島行正, 西川 潔: 学振54委, 化工 小委71（1975年 5 月）

5 ) 桑原 守, 鞭 厥：鉄と鋼，62(1976), p. 463

6 ) $V$. Stanek and $J$. Szekely: Canad. J. Chem. Eng., 50(1972), p. 9

7) $V$. Stanek and $J$. Szekely: AIChE Journal, $20(1974) 5$, p. 974

8 ) 羽田野道春, 栗田興一: 鉄と鋼, 62(1976), p. 953

9 ）荒木和男，森山 昭：鉄と鋼，63(1977)，p.1035

10) $J$. Radestock and $R$. Jeshara: Stahl u. Eisen, 90(1970), p. 1249

11) $J$. Radestock and $R$. Jeshara: Chemie. Ing. Techn., 43(1971), p. 355

12) $J$. Radestock and $R$. Jeshra: Chemie. Ing. Techn., 43(1971), p. 1304

13) $J$. Szekely and $J$. $J$. Poveromo: AIChE Journal, 21(1975), p. 769

14) T. Fukutake and $K$. Okabe: Trans. ISIJ, 16 (1976), p. 189

15）桑原守，近松栄二，鞭㟟：鉄と鋼，62 (1976), S 42 